\title{
Anabaptist two kingdom dualism: metaphysical grounding for non-violence
}

\author{
Caleb Zimmerman (1) \\ Department of Philosophy, Temple University, 1801 N Broad St, Philadelphia, Pennsylvania, \\ 19122, USA \\ Email: Caleb.zimmerman@temple.edu
}

(Received 8 July 2020; revised 30 March 2021; accepted 31 March 2021)

\begin{abstract}
A non-violent position drawn from the Anabaptist tradition ('two-kingdom dualism') is contrasted with the Christian pacifism with which that position is commonly conflated. It is argued that twokingdom dualism more effectively leverages the philosophical and practical features of its particularly Christian character than does Christian pacifism - and that these features may have implications beyond the philosophy of religion.
\end{abstract}

Keywords: Anabaptism; pacifism; Mennonite; just war; metaphysics; Kierkegaard; two-kingdom dualism

This article argues that a non-violent position with roots in Mennonite thought has important advantages over Christian pacifism. The article proceeds as follows. First, I argue that Christian pacifism exhibits the same moralist conceptual structure as do the vast majority of pacifist positions unassociated with Christianity - and that this conceptual structure places the particularly Christian character of Christian pacifism in a precarious position. Second, I identify in the Mennonite tradition a conception of non-violence ('two-kingdom dualism') that I argue is not a species of pacifism. Finally, I contend that its metaphysical conceptual structure equips two-kingdom dualism to leverage the practical and philosophical features of its Christian character more effectively than does Christian pacifism.

\section{Christian pacifism}

Let us call 'pacifist' those positions that oppose war and violence on moral grounds. If this definition holds, then by extension, 'Christian pacifism' describes opposition to war and violence on specifically Christian moral grounds. Thus defined, Christian pacifism seems a fitting label for the social activism of such figures as Dorothy Day and Martin Luther King Jr in the last century, as well as for the non-violent position of American Quakers a century earlier. The Quakers' 1838 Declaration of Sentiments, for instance, advocated a 'peaceful universal reformation' and declared that 'physical coercion is not adapted to moral generation' (accordingly, the Declaration deemed the bearing of arms 'unlawful'). ${ }^{1}$ 
This Christian pacifist appeal to the immorality of violence is straightforward and familiar. It invokes what the Christian pacifist regards as a basic and universal imperative to adhere to acts deemed moral or right and refrain from acts deemed immoral or wrong. What makes her appeal particularly Christian, meanwhile, is that for the Christian pacifist Christianity is what verifies or corroborates the claim that violence is wrong; put a different way, the value of Christian pacifism's specifically Christian character consists in the role that Christianity is thought to play in underwriting or grounding the Christian pacifist's judgement that violence is correctly called immoral. Accordingly, we can conceive of the Christian pacifist as one kind of Christian moralist; what distinguishes the Christian pacifist in particular is just that, unlike most Christian moralists, the Christian pacifist adds violence to the set of things that she thinks Christianity morally proscribes.

The moralist conceptual structure that characterizes Christian pacifism - that is, its primary responsiveness to what is taken by the Christian pacifist to be a basic and universal imperative to act morally - has two seeming advantages. First, the Christian pacifist's conviction that non-violence is universally morally imperative sanctions a globally proportioned activist programme according to which the Christian pacifist might attempt to hold individuals and governments of all kinds to that imperative. In this way, for instance, the Mennonite Central Committee organizes political protests and lobbies government agencies from its office at the United Nations headquarters, while Christian Peacemaker Teams employ activists around the world whose slogan is 'getting in the way' of violent conflicts. ${ }^{2}$ Second, the moralist conceptual structure of Christian pacifism facilitates collaboration between Christian pacifists and like-minded opponents of war and violence who are unassociated with Christianity. If a Christian pacifist converges on the same violent humanitarian crisis as a Hindu aid worker and a religiously unaffiliated UN peacekeeper, for instance, the Christian pacifist can regard these differences as secondary to the workers' shared conviction that violence is wrong.

But the moralist conceptual structure that generates these advantages also places the particularly Christian character of Christian pacifism in a precarious position. This precarity is a consequence of the instrumental role that Christianity plays within that structure: the value that Christianity contributes to Christian pacifism consists in Christianity's ability to serve as a means to the end of establishing the immorality or wrongness of violence. This role would be indispensable and secure if Christianity were either (1) the only means to that end or (2) able to achieve that end in some distinctive or especially valuable way. But Christianity is neither (1) nor (2).

First, Christianity is but one of many means to the end of establishing violence's wrongness. That is, in appealing primarily to the immorality of violence, Christian pacifism mirrors the moralist conceptual structure of most (if not all) mainstream pacifist models in the contemporary literature. For instance, a variety of moralist accounts of nonviolence are readily derived from Kant's thought. The Kantian might base her claim that violence is immoral on Kant's Categorical Imperative, for instance, or on his universal law formula, his legislative perspective, or his insistence that citizens have no right to destroy their legal system by resisting or coercing heads of state. ${ }^{3}$ Further, the Kantian might argue that violence and war are immoral in virtue of their violation of Kant's humanity formula or their failure to treat humans as ends in themselves. ${ }^{4}$ Alternatively, Stephen White argues that violence that is coercive is immoral because it attempts unfairly to shift moral responsibility onto its victim and cause that victim to pursue actions that she would not otherwise have reason to pursue. ${ }^{5}$ For Sally Haslanger, meanwhile, violence is immoral because it is oppressive, while for Thoreau, resistance to violence is a performance of conscience deriving from the moral ideal of self-reliance. ${ }^{6}$ Robert Holmes takes himself to show quite easily that violence is at least prima facie immoral merely in virtue of its being harmful, while for Robert Paul Wolff, an attractively simple paradigm for 
pacifism derives from a utilitarian or consequentialist calculus, since the cessation of war and violence is almost certain to bring about a greater good for a greater number. ${ }^{7}$

These examples suggest that Christianity is just one among a plethora of possible ballasts for the claim that violence is immoral. of course, it does not follow from this that Christianity cannot still play an indispensable role in Christian pacifism's conceptual structure, since Christianity might still ground the immorality of violence in some distinctive or especially valuable way. But Christianity does not ground the immorality of violence in this way; Christian pacifism's moral proscription of violence does not have a particularly Christian character. Instead, an effect of assessing an act using clean and neutral moral terms is precisely to veil whatever particular considerations may have contributed to this assessment. This is because moral assessments seek to determine whether a substantial and basic property of rightness or wrongness inheres in a given act; the pacifist, for instance, considers the wrongness of violence a substantial and basic property that by itself constitutes sufficient grounds for demanding universal desistance from violence. Given this reasoning structure, once the moralist establishes that violence is wrong, it no longer matters whether this wrongness derives from Christianity or a postulate of reason or something else. What matters is the conclusion, and the conclusion is the same: that violence is wrong. ${ }^{8}$

Thus, while the Christian pacifist's clean and neutral moral terms give her prescription of violence a pretence of universal and equal application even to those who would not have credited the particularly Christian considerations that might underlie it, those same universal pretensions actually depend on the independence of the immorality of violence from any essentially Christian resources. If the Christian pacifist's denunciations of violence betrayed a particularly Christian essence, on the other hand, they would fail to serve her universal activist campaign against violence. Unless directed towards an explicitly Christian audience, they would fall on deaf ears.

These considerations demonstrate that to the extent that a non-violent Christian position depends on appeals to the wrongness or immorality of violence, the particularly Christian character of that position is neither essential nor immediately evident. If Christianity merely plays the role of affirming that violence is immoral, then its role is dispensable and its personality muted, since other sources of grounding could also play its role, and morality's essential structure prevents Christianity from playing its role in a distinctive or especially valuable way: as seen, the whole point of casting violence as immoral is to apply its proscription neutrally and universally and thus without dependence on any essentially Christian commitments. These results suggest that if Christianity is to play an essential role in the conceptual structure of a non-violent position, that role will not be a moral one. A more promising Christian non-violent model would leverage its particularly Christian character by deploying Christianity as something other than a ballast for the claim that violence is immoral. ${ }^{9}$

\section{Two-kingdom dualism}

The exemplars of Christian pacifism mentioned above - Christian Peacemaker Teams and the Mennonite Central Committee - are affiliates of the Mennonites, whose Christian tradition is of the same genus as the pietist, Anabaptist, Moravian, Brethren, and Quaker movements of the Radical Reformation. ${ }^{10}$ Mennonite non-violent practice has developed since the movement's founding in the early sixteenth century, when their theological convictions costed many of the first Mennonites their lives. ${ }^{11}$ Traditional Mennonite non-violent theory differed significantly from pacifism, however, and the confluence of Mennonites and Christian pacifism is a recent development accompanying a mainstream rise in activist political engagement since the Vietnam War. ${ }^{12}$ At earlier 
points in their history, Mennonites modelled a distinctive kind of non-violent action brimming with noteworthy philosophical and practical implications but in an important sense antithetical to Christian pacifism. This position is two-kingdom dualism.

Two-kingdom dualism is characterized by a conceptual structure significantly different from - and arguably directly opposed to - the one that characterizes Christian pacifism. The two-kingdom dualist's reasoning begins not from a universal and overriding imperative to act morally but from a subject's arguably more basic disposition or instinct to align her actions with what she thinks is real. ${ }^{13}$ The conception of Christianity deployed by twokingdom dualism is thus a metaphysical one that casts Christianity as most fundamentally an invitation to participate in a narrative purporting to describe reality. To be a Christian on this conception is therefore not to adhere to Christian standards of morality but rather to participate in this narrative as if it did indeed describe reality. ${ }^{14}$

Accordingly, while moral considerations play a basic role within the conceptual structure of Christian pacifism, metaphysical considerations play that role in the conceptual structure of two-kingdom dualism: what she considers real on the basis of her Christian faith - as opposed to what she considers moral or 'right' - constitutes the twokingdom dualist's most privileged criterion for action. ${ }^{15}$ Three features of this reality are of particular significance in shaping the two-kingdom dualist's thinking about nonviolence. First, the Christian narrative suggests that love plays a perennial role in the world irrespective of human activity. That is, love is not conjured up by humans and imposed on a world where it would not otherwise inhere; instead, a fundamental feature of reality as the Christian understands it is that the world is penetrated from the outside by the love of a supreme being. ${ }^{16}$ The claim that we love because God first loved us suggests that even in cases where its particular manifestations are not merited, precedented, or reciprocated, love is a reasonable and reciprocal response to the world's pre-existing and indeed fundamental condition. ${ }^{17}$

Secondly and relatedly, the Christian narrative casts self-sacrifice, like love, as having a precedent outside humanity in the highest being. That is, the dualist understands Jesus's death not as a source of moral inspiration or prototypical instantiation of a moral principle but rather as an event with which reality is consonant. In light of this event, a Christian's sacrifice of self is not a morally salutary act imposed on a world whose more fundamental modus operandi is a violent struggle for survival but rather an altogether natural act built by the highest being into the elemental fabric of reality.

But two-kingdom dualism arises most directly out of the distinctive logical space carved out by a third feature of Christian metaphysics: its bifurcation of reality into two kingdoms. This move follows from the biblical teaching that Christians, who live alongside everyone else in the kingdom of the world, are also to 'seek first' a different kingdom - the 'kingdom of God'. ${ }^{18}$ This 'seek first' suggests that the domains of the kingdom of God $\left(\mathrm{K}_{\mathrm{G}}\right)$ and the kingdom of the world $\left(\mathrm{K}_{\mathrm{W}}\right)$ are in principle distinct: each operates according to reference points that may be unavailable, inapplicable, or even unintelligible in the other. But it also suggests that the line dividing the two kingdoms can be clearly drawn, given that it runs not between heaven and earth but between mutually exclusive professions of allegiance: while $\mathrm{K}_{\mathrm{W}}$ is comprised of citizens whose primary allegiance is to their earthly nations, to themselves, to some other thing, or to nothing, $\mathrm{K}_{\mathrm{G}}$ is composed of citizens whose primary allegiance is to God. ${ }^{19}$

Accordingly, a potentially awkward implication of two-kingdom dualism is that citizens of $\mathrm{K}_{\mathrm{G}}$ must somehow live in two kingdoms at once, since they must also literally reside in particular kingdoms in the world. But this fact need not generate an irremediable tension: for one thing, the actions that align with allegiance to God and those that align with allegiance to authorities in the kingdom of the world might in principle coincide; when this occurs, citizens of $\mathrm{K}_{\mathrm{G}}$ simply act in the same way as do citizens of the kingdom of the 
world. Meanwhile, when their two allegiances do not coincide, citizens of $\mathrm{K}_{\mathrm{G}}$ are provided with an apparently sufficient criterion: 'Give to Caesar what is Caesar's and to God what is God's. ${ }^{20}$

This criterion makes clear that the citizen of $\mathrm{K}_{\mathrm{G}}$ does not regard her allegiance to her authorities in $\mathrm{K}_{\mathrm{W}}$ as absolute: while some things belong to Caesar, others do not. ${ }^{21}$ But the criterion also implies that the jurisdictions of the two kingdoms do not in principle conflict; anything that belongs to one king ipso facto does not belong to the other. Determining what belongs to each king may not be easy, of course, but the question of whether it belongs to the king of $\mathrm{K}_{\mathrm{W}}$ to demand that his citizens act violently on his kingdom's behalf appears quite simple, since it is a question of whether his citizens' very bodies and lives - as well as the bodies and lives of his enemy - belong to that king. On this question, the Christian's scriptural inheritance is clear: the Christian submits her body not to her worldly king but to God as a 'living sacrifice'. ${ }^{22}$ Violence, meanwhile, is difficult (though perhaps not impossible) to reconcile with the love and self-sacrifice that the citizen of $\mathrm{K}_{\mathrm{G}}$ believes characterize $\mathrm{K}_{\mathrm{G}}{ }^{23}$ Since $\mathrm{K}_{\mathrm{G}}$ transcends national and ethnic distinctions and persists irrespectively of them, moreover, the citizen of $\mathrm{K}_{\mathrm{G}}$ has no essential interest in the fate of a particular worldly kingdom - even her own. ${ }^{24}$ Accordingly, for the citizen of $\mathrm{K}_{\mathrm{G}}$ to act violently on behalf of $\mathrm{K}_{\mathrm{W}}$, offer her life for the causes of $\mathrm{K}_{\mathrm{W}}$, or allow her leaders in $\mathrm{K}_{\mathrm{W}}$ to dictate who counts as her enemy is for her to fail to align with what she regards as reality - with her supreme allegiance to $\mathrm{K}_{\mathrm{G}}$ and with the metaphysical features that she thinks characterize $\mathrm{K}_{\mathrm{G}}{ }^{25}$

This broad sketch demonstrates that two-kingdom dualism inverts the conceptual structure that characterized Christian pacifism. That is, just as metaphysical considerations were peripheral to the 'morality-first' conceptual structure of the Christian pacifist whose claim that violence is immoral was independent of particular metaphysical considerations - moral considerations are peripheral to the 'metaphysics-first' conceptual structure of two-kingdom dualism, since its claim that violence is generally misaligned with reality Christianly understood makes no appeal to the immorality or wrongness of violence. ${ }^{26}$ But this claim that two-kingdom dualism elevates metaphysical considerations to the potential exclusion of moral ones is likely to raise an important question, since a perhaps more conventional position maintains that Christian moral considerations are concomitant with and even inextricable from metaphysical ones. 'Why not both?' a proponent of this position might ask. Why not 'add' the moral implication to the metaphysical commitment, so to speak, and treat the two as different aspects of the same thing?

In response to this question, it is important to clarify that two-kingdom dualism does not suggest that a non-violent account primarily responsive to Christian metaphysics cannot or should not also be articulated in moral terms. What it does suggest, however, is that the Christian does not need these moral terms; it remains to be seen, moreover, whether there is anything to be gained from including them. After all, as our earlier discussion of Christian pacifism suggested, moral terms that are essentially tied to a particularly Christian metaphysical schema are either unintelligible for the person who has not adopted such a schema or redundant and relatively uncompelling for the person who has. On the one hand, if a person does regard Christianity as a source of significant information about reality and describes non-violence in terms of its alignment with this reality, then it is quite unclear what substance or value some further quality of 'rightness' would contribute - why she should bother with 'rightness' rather than letting Occam's Razor shave it away. ${ }^{27}$

On the other hand, if a person does not hold that the Christian metaphysical claims with which the Christian's non-violent action is aligned significantly track reality, then she cannot be expected to credit in any way the behavioural implications of those claims. Moreover, attempts to use moral terms to try to extend the behavioural implications of 
Christian metaphysical commitments to persons who lack those commitments are likely to be riddled with complications. For one thing, such attempts generate confusion, since using the term 'moral' to describe acts that are essentially grounded in particularly Christian metaphysical considerations is wildly different from using it in any sense that is familiar in $\mathrm{K}_{\mathrm{W}}$, where 'moral' denotes what the citizen of $\mathrm{K}_{\mathrm{W}}$ regards as an act's basic and substantial property of rightness. Second, the Christian pacifist's attempts to influence the citizen of $\mathrm{K}_{\mathrm{W}}$ through appeal to the clean and neutral 'wrongness' of violence would be odd sleights of hand if a particularly Christian conception of reality actually played an essential role in the Christian pacifist's own conception of nonviolence; indeed, the attempt is evidence that such a conception does not play an essential role in her own non-violent position. Moreover, if Christians' non-violent action does in fact depend on particularly Christian metaphysical commitments, then the Christian pacifist's moral demands might actually be unreasonable or unfair, since the citizen of $\mathrm{K}_{\mathrm{W}}$ who lacks those commitments may not even be practically capable of the radically non-violent action that would follow from them. ${ }^{28}$

These difficulties cast as manifestly odd the Christian's attempt to induce a person who has not adopted a Christian metaphysical schema nonetheless to align her acts with the behavioural implications of that schema on the basis that doing so is supposedly moral. Indeed, it is quite unclear what the Christian stands to gain from this manoeuvre - or even what the Christian thinks the citizen of $\mathrm{K}_{\mathrm{W}}$ stands to gain from it. It seems that the oddness merely reinforces the point that moral terms are what a person resorts to appeal to precisely when appeal to metaphysical considerations is not possible. That is, since the Christian pacifist cannot appeal to the domain of reality when petitioning someone who does not think that the Kingdom of God is real, her best recourse is to the claim that violence is wrong, which might still have some effect.

Having now seen some evidence of two-kingdom dualism's distinctive theoretical character, let us also consider several objections. First, two-kingdom dualism might appear to be caught in a contradiction or double standard in which it recommends one act for citizens of $\mathrm{K}_{\mathrm{G}}$ and a quite different one for citizens of $\mathrm{K}_{\mathrm{W}}$. Second, two-kingdom dualism seems to exhibit a radical form of religiosity known to be dangerous: the problem with religious crusaders or terrorists, it may be thought, is precisely the fact that their responsiveness to what they consider real places them beyond the reach of moral censure.

The two-kingdom dualist can concede both of these objections, however. First, twokingdom dualism does indeed commend different actions to citizens of different kingdoms, but this fact is a reasonable and inevitable function of the dramatically divergent metaphysical commitments of these citizens. It is unclear, moreover, why this difference constitutes a theoretical liability for two-kingdom dualism rather than grounds for a salutary kind of pluralism. Likewise, the two-kingdom dualist acknowledges that the conceptual structure of her position is quite radical. Yet, she can also reasonably maintain that she is not liable for this fact, since she regards $\mathrm{K}_{\mathrm{G}}$ as a reality undetermined by her and in which she merely participates. Moreover, she might argue that the danger inherent to her position's metaphysics-first conceptual structure is a worthwhile trade-off for a position uniquely capable of motivating radically non-violent action. ${ }^{29}$

But a third objection - that two-kingdom dualism amounts to a species of relativism is unfounded, since it does indeed follow from two-kingdom dualism that some alignment with the kingdom of God is beneficial and even in an important sense imperative for citizens of $\mathrm{K}_{\mathrm{W}}$. Yet, what prevents two-kingdom dualism from amounting to relativism are not universal or categorical moral claims but precisely metaphysical claims. That is, the dualist recognizes that if $\mathrm{K}_{\mathrm{G}}$ is real, then the most fundamental and compelling consideration for citizens of both $\mathrm{K}_{\mathrm{G}}$ and $\mathrm{K}_{\mathrm{W}}$ is not the immorality or wrongness of an act that is misaligned with $\mathrm{K}_{\mathrm{G}}$ but rather the actor's essential misalignment with reality. Put in 
Kierkegaardian terms, this actor is 'not herself' - not 'resting in the power that establishes her' - and missing out on 'the good that God has for her' as a result. ${ }^{30}$ Her sin is not the immorality or wrongness of her particular acts but this encompassing metaphysical misrelation to God and $\mathrm{K}_{\mathrm{G}}$.

Accordingly, the kingdom of God presents the citizen of $\mathrm{K}_{\mathrm{W}}$ not with a panoply of religiously motivated moral imperatives but with a single metaphysical imperative: to align with reality by becoming a citizen of the kingdom of God. But even this one imperative act is imperative not because joining the kingdom of God is moral but because the kingdom of God is real. There is still nothing to be gained from alluding to the morality or rightness of joining the kingdom of God or of any related act. ${ }^{31}$

The considerations of this section cast doubt on the common and more general idea that fundamentally metaphysically grounded acts can be properly called moral. They also suggest that whether or not it is possible to do so, there is nothing to be gained from referring to a Christian's metaphysically grounded acts in moral terms. When a farmer responds to the reality that his fields are ripe by going out and harvesting them, we do not say that he did the 'right' thing; perhaps we could describe his act in moral terms, but doing so has no clear advantage, and it may invite more confusion than it is worth. The argument of this section is that the Christian who tries to align her action with reality is like the farmer; her act is of the same kind. Understanding her act in moral terms, even if possible, has no clear advantage and might invite more confusion than it is worth. ${ }^{32}$

\section{Practical implications}

The previous section argued that two-kingdom dualism can theoretically ground nonviolence without reference to moral considerations and only through appeal to a kind of Christian realism. ${ }^{33}$ This section examines six further features generated by twokingdom dualism's metaphysical conceptual structure.

First, its metaphysical conceptual structure exempts two-kingdom dualism from the dissident or antagonistic posture towards state and military actors that most non-violent positions entail. By contrast, sixteenth-century two-kingdom dualists concluded from the biblical teaching that 'the powers that be are ordained by God' that 'the sword is ordained by God outside the perfection of Christ'. ${ }^{34}$ This position stakes out a radical middle ground between just war theory, which uses the same scriptural reference to argue that even the citizen of $\mathrm{K}_{\mathrm{G}}$ must use the sword when the state demands it, and Christian pacifism, which morally condemns the state's use of the sword. ${ }^{35}$ Where Christian pacifists might 'wage war through nonviolent means', using moral claims to 'take on' governments and attempt to 'force' cessations of violence, the two-kingdom dualist can 'affirm' and even assist the state as the God-appointed overseer of $\mathrm{K}_{\mathrm{W}}$ - so long as doing so does not involve violence on the state's behalf. ${ }^{36}$

In times of compulsory military service, this unusual perspective has led to extraordinary meetings between government officials and two-kingdom dualists forthrightly appealing for alternative non-violent forms of service. Two-kingdom dualists in positions like these manifest a remarkable fusion of qualified allegiance and overt defiance: 'We are in a tough position and prepared to suffer for it, but could we work out a deal that could be good for us and for the country? ${ }^{37}$ The resultant truce - in which dualists refrain from telling the state how to govern the affairs of $\mathrm{K}_{\mathrm{W}}$ while the state allows dualists to quietly align their actions as best they can with $\mathrm{K}_{\mathrm{G}}$ - is one that the pacifist could not even attempt, since the pacifist's moralist position places herself and the government under the same obligation and thereby obliges her to condemn government military action. $^{38}$ 
A second practical feature that this cooperative posture towards the state facilitates is that it frees two-kingdom dualists from a contradiction that plagues pacifist humanitarian workers in conflict zones. These workers face an awkward problem of their own making when, in order to perform their humanitarian duties, they find themselves dependent on the protection of the same violent military forces that they morally condemn. In such cases, pacifists face what Showalter calls a 'crisis of conscience' that might prompt them to decline military assistance - while those they would have helped pay the price. ${ }^{39}$ The dualist, meanwhile, faces no such predicament: since her position affirms the state, she gratefully and consistently accepts its support and even military assistance. ${ }^{40}$

A third practical implication of two-kingdom dualism's metaphysical conceptual structure is that non-violent action need not be performed in an activist spirit that seeks to goad others towards the same action (an ethos that is common if not endemic among pacifists). This is because two-kingdom dualism is not responsive to universal moral injunctions: the two-kingdom dualist demurs from denouncing violence by citizens of $\mathrm{K}_{\mathrm{W}}$ (since violence is quite commensurable with $\mathrm{K}_{\mathrm{W}}$ ), and she may in principle even countenance violence by citizens of $\mathrm{K}_{\mathrm{G}}$ (since some violence may conceivably be commensurable with $\mathrm{K}_{\mathrm{G}}$ ). ${ }^{41}$

This result suggests a fourth and similar practical implication: that the two-kingdom dualist is not bound by categorical injunctions. Can a citizen of $\mathrm{K}_{\mathrm{G}}$ kill? Can she use force? Can she vote or hold office? In response to questions like these, two-kingdom dualism's metaphysical framework provides practical ethical guidance, not categorical moral rulings, thereby placing a premium on wisdom, discernment, and even the guidance of the Holy Spirit. While this puts two-kingdom dualism in tension with moralist accounts that do issue categorical injunctions, it can also facilitate greater nuance and responsiveness in the two-kingdom dualist's practical deliberations.

A fifth feature lies in this vicinity. As seen above, a perceived feature of moral judgements is that they purport to compel universal compliance. A person can in some sense 'choose' not to comply with a moral injunction, but only at the cost of being designated immoral and inviting the unmoored opprobrium that concerned Nietzsche. ${ }^{42}$ Meanwhile, to free non-violence from the domain of moral obligation is perhaps two-kingdom dualism's most important achievement. Two-kingdom dualism dignifies the non-violent citizen of $\mathrm{K}_{\mathrm{G}}$ by portraying her non-violence not as a strained response to a moral injunction but as a contingent and uncoerced choice to align her action with a reality that she could also have chosen to defy. ${ }^{43}$

Finally, as suggested above, two-kingdom dualism's independence from moral considerations gives it a motivational advantage over pacifism. Given that non-violent commitment is likely to be radical and costly - and to be subjected to the charge that it is itself 'deeply immoral' - a non-violent model's ability to motivate adherence on more than merely moral grounds may be essential. ${ }^{44}$ After all, when a person is faced with a threat to her life, an abstract imperative to be moral may fall flat as a motivational basis for a non-violent response. But while few are likely to give up their lives for a moral abstraction, many have non-violently acquiesced even to death when confident that in doing so, they could participate in what they consider real.

\section{Notes}

1. Tolstoy (2009), 17-20. The conception of non-violence that Tolstoy himself later defends is closer to the metaphysical one discussed below (ibid., 172-173).

2. Whitworth (2014); Christian Peacemaker Teams are known to publicly reprimand soldiers and state officials for their violence; at the time of writing, for instance, the organization's website featured a Caucasian protester shouting through a bullhorn at the driver of a bulldozer in the West Bank.

3. Hill (1997), 116-125, 128-135. See also Curtis-Wendlandt (2012), 766-769. 
4. Hill (1997), 105-106.

5. White (2017), 200-208.

6. Haslanger (2012), 98-100. See also Turner (2005, 449-55)

7. Holmes (1973), 403-404; Wolff (1969), 615. The list could go on. According to Arnold (2018), for instance, violence is not just immoral, but a cause for 'moral horror'.

8. This is why the person who appeals to religion or ideology or anything else in an attempt to modify or claim exemption from moral claims is less likely to succeed than to invite charges of immorality against the religious or ideological or other basis for her claim to exemption. Such a person seems not to have understood what morality is - that for an act's wrongness to purport to compel universal desistance from the act merely on the basis of its wrongness is simply what is meant by calling it wrong.

9. Importantly, my account suggests a distinction between moral questions pertaining to whether a given act is right or wrong and broader ethical questions pertaining to whether an act is engaged in reasonably or consistently, which might be asked without reference to moral considerations.

10. Estep (1995), 151-176.

11. Van Bragt (2010).

12. Weaver (2017), 241-242.

13. In calling the latter disposition 'more basic', I am maintaining that people can seek to align their acts with what they regard as real without reference to whether those acts are moral or right. For more on this point, see note 9.

14. The dualist maintains that whether this narrative is factual, fraught with error, or outright false, its proper domain is metaphysical; see Yoder (1972), 62-63:

Jesus was not just a moralist whose teachings had some political implications . . Jesus was ... the bearer of a new possibility of human, social, and therefore political relationships. His baptism is the inauguration and his cross the culmination of that new regime in which his disciples are called to share. Men may choose to consider that kingdom as not real, or not relevant, or not possible...

To regard Christianity as a fundamentally metaphysical position is not to claim that one knows anything at all about reality or about how or whether Christianity aligns with it; indeed, it does not amount to a claim of any kind about one's particular propositional attitude towards Christianity. Instead, all it designates is an acknowledgement that Christianity presents itself as an account of some important features of reality. As a result, two-kingdom dualism does not defy protests like the one from Kant's first Critique that we cannot know anything about God-in-Godself. Kant, himself a pietist, leaves the reality of the noumena unquestioned and proffers Glaube or 'Belief' as a robust propositional attitude better proportioned to the particularities and limitations of human reason (see Kant (1999), 643-644; see also Chignell (2007))." This sort of propositional attitude is more than sufficient to sustain a metaphysical conception of Christianity, since the essence of this conception is not the strength of the two-kingdom dualist's particular propositional attitude but just the fact that the two-kingdom dualist reasons from propositional attitudes whose objects she regards as real. In other words, whether in the end those attitudes amount to belief or faith or knowledge or something else is orthogonal to the structure of the dualist's reasoning.

15. Indeed, two-kingdom dualism lends itself to moral anti-realism in that what she takes to be real could in principle constitute the two-kingdom dualist's only criterion for action.

16. For a poignant illustration of this claim see Kierkegaard's parable of the king and the maiden in Philosophical Fragments (Kierkegaard (1985), 23-54).

17. 1 Jn. 4:19 (ESV). J. M. E. McTaggart is one of several philosophers who argue that love can be considered a constituent of reality on a naturalist metaphysical schema (McTaggart (1927), 436-440). Yet, like Kant but unlike two-kingdom dualism, McTaggart portrays love as a merely contingent human experience and not grounded in reality in such a way that it would persist if no person conjured it up.

18. Mat. 6:33 (ESV). This Kingdom is described as the 'Kingdom of Heaven' in Mat. 18:3 and 19:23 (ESV), whereas Augustine uses 'City of God' (Augustine (1998)).

19. A simple but sufficient definition for the kingdom of God, therefore, is 'the place where God is king'.

20. Mk. 12:17 (ESV).

21. Although it purports to develop out of a principled allegiance to Caesar, just war theory shares this subversive premise. While permitting violent acts such as killing that would otherwise be considered immoral if they are committed in compliance with a sovereign's command in a just war, just war models do not maintain that one's obedience to that sovereign is absolute even in a just war. If the sovereign instructs its citizen to torture, rape, or dismember the enemy, for instance, just war theory morally obligates this citizen not to comply (the execution of war criminals in the Nuremberg trials for crimes committed while under orders testifies to the 
limited scope of what is considered reasonable allegiance to Caesar). But if a citizen's wartime obedience to her sovereign is contingent even for proponents of war, one might ask why this line is drawn where it is (somewhere between killing and torture) instead of before killing or even before violence of any kind.

22. Rom 12:1 (ESV).

23. Additionally, violence defies the command of the king of $K_{G}$ to 'love your enemies' (Matt. 5:44 [ESV]). While this injunction may appear to be morally inflected, its force, for the two-kingdom dualist, derives from the metaphysical supremacy of the God whom the dualist believes gave the command, not from the injunction's abstractly or 'queerly' moral correctness (see Mackie (1977), 38-42). That is, the reality of divine commands enjoys a kind of logical priority that constitutes a sufficient basis for obedience. Meanwhile, a moral evaluation of these commands would effectively ignore the fact that their reality precedes and persists irrespectively of this evaluation (for more on this difference between divine commands and moral principles, see Kierkegaard's distinction between a genius and an apostle in Kierkegaard (1997), 93-108).

24. Jn. 18:36 (ESV): 'My kingdom is not of this world; if it were, my servants would fight.' Tolstoy applauds this sentiment and identifies it in the declaration of the Peace Convention held in Boston in 1838, which states, 'We can allow no appeal to patriotism to revenge any national insult or injury.' But the Convention undermines the two-kingdom dualist sentiment embodied here with its later declaration that 'the dogma that all the governments of the world are approvingly ordained by God, and that the powers that be . . . are in accordance with his will, is no less absurd than impious. It makes the impartial Author of our existence unequal and tyrannical.' The two-kingdom dualist might point out that the author of Romans 13 claims only that these powers are ordained by God, not that they are ordained 'approvingly' or that they always act 'in accordance with his will'. In any case, these lines make clear that the Convention is primarily responsive to moral considerations (i.e. pacifist) (Tolstoy (2009), 10).

25. Meanwhile, attempts to motivate non-violence in $\mathrm{K}_{\mathrm{W}}$ through reference to what citizens of $\mathrm{K}_{\mathrm{W}}$ regard as real are unpromising: since those citizens regard $\mathrm{K}_{\mathrm{W}}$ as the product of a long struggle throughout which natural selection has rewarded the more violent with survival, it is difficult (though again perhaps not impossible) for the non-violent actor in $\mathrm{K}_{\mathrm{W}}$ to argue that violence is incongruous with what citizens of $\mathrm{K}_{\mathrm{W}}$ regard as real. As a consequence, the best recourse of the proponent of non-violence in $\mathrm{K}_{\mathrm{W}}$ is to the claim that violence is immoral.

Of course, it does not follow that non-violence will come more naturally to the citizen of $\mathrm{K}_{\mathrm{G}}$ than it does to the citizen of $\mathrm{K}_{\mathrm{W}} ; \mathrm{K}_{\mathrm{G}}$ is not immune to the challenges that often incline $\mathrm{K}_{\mathrm{W}}$ towards violence. Indeed, this fact merely underscores the importance for the citizen of $\mathrm{K}_{\mathrm{G}}$ of her regular, public, and communal profession of allegiance to $\mathrm{K}_{\mathrm{G}}$. Unlike a solitary Thoreau acting on unilaterally contrived moral fervour or from a perceived moral obligation, the citizen of $\mathrm{K}_{\mathrm{G}}$ chooses to make a public and communal commitment to $\mathrm{K}_{\mathrm{G}}$ (for more on this, see the fifth practical implication outlined in Part III). Citizens who have made such commitments of highest allegiance to $\mathrm{K}_{\mathrm{G}}$ then also hold each other to those commitments by practising them communally.

26. In terms of necessary and sufficient conditions, the metaphysical consideration is sufficient while the moral one is unnecessary.

27. David Wolfsdorf's analysis of 'goodness' may be helpful here. For Wolfsdorf, goodness is that which significantly serves a given purpose; moral language, accordingly, is intelligible to the extent that an act called 'good' or 'right' serves the purpose of advancing a particular moral objective (see Wolfsdorf (2019), 89-138). The point of my analysis, in Wolfsdorf's terms, is that the purpose that renders the Christian's action intelligibly 'good' is always fundamentally alignment with metaphysical objects and states of affairs. As a result, the two-kingdom dualist's use of 'goodness' has no moral sense - if 'goodness' is predicated at all, it is predicated not prescriptively but descriptively to denote acts that are thought to serve the purpose of aligning with the metaphysics of $\mathrm{K}_{\mathrm{G}}$. 28. The 'ought implies can' principle suggest that if the citizen of $\mathrm{K}_{\mathrm{W}}$ ought to act non-violently, then she can do so; consequently, for the Christian pacifist to suggest that the citizen of $\mathrm{K}_{\mathrm{W}}$ ought to act non-violently is for her to effectively concede that there is nothing about her particularly Christian position that uniquely equips her to act non-violently. But from the perspective of two-kingdom dualism this is highly implausible, since it is precisely the dualist's distinctively Christian beliefs about reality that render her non-violent action practicable in the first place; without these resources, and if she were equipped only with an abstract sense that 'violence is wrong', she may not find herself capable of sustaining her non-violent practice. Indeed, the role of the Holy Spirit in this connection - in equipping and motivating non-violent action - must also not be overlooked, since it is arguably indispensable to the durability of the Christian's non-violent practice (Lk. 12:12 [ESV]). But then if the Holy Spirit plays such an essential role in enabling the Christian to act non-violently, an insistence that a person who lacks the Holy Spirit must nonetheless act non-violently violates 'ought implies can'.

29. For more on this point, see the sixth practical implication of two-kingdom dualism outlined below.

30. Kierkegaard (1983), 96.

31. This switching of kingdoms by the citizen of $\mathrm{K}_{\mathrm{W}}$ need not constitute a 'leap of faith', however. Instead, like someone whose cost-benefit analysis prompts her to immigrate to a different place, the citizen of $\mathrm{K}_{\mathrm{G}}$ makes an 
uncoerced but potentially reasonable judgement on the basis of observing both kingdoms that switching kingdoms may be more conducive to her flourishing.

32. This feature of two-kingdom dualism may add some colour to the common impression that Anabaptism is both in an important sense within the orthodox Christian tradition and in an important sense distinct from more mainstream Christian positions. That is, while Anabaptism depends on the same metaphysical commitments that have sustained Christians across the centuries, the style of political engagement that Anabaptists take to follow from these commitments contrasts markedly with both liberal and conservative models of Christian political engagement. Whereas the latter models endorse opposite visions of what the universal adoption of christian morality might look like, Anabaptists at least historically modelled what James Davidson Hunter has called 'faithful presence' by living quiet and simple lives and concerning themselves primarily with aligning their own action as best they could with their Christian metaphysical commitments (see Hunter (2010), 150-166 and 238-254). While such Anabaptists actively encourage citizens of $\mathrm{K}_{\mathrm{W}}$ to join $\mathrm{K}_{\mathrm{G}}$, they regard as incoherent attempts to extend an ethic of $\mathrm{K}_{\mathrm{G}}$ to those whose allegiances are still to $\mathrm{K}_{\mathrm{W}}$.

33. It might seem that two-kingdom dualism is not philosophically distinctive in this regard because Kant also provides a framework for morality that avoids relying on Christian resources while locating a metaphysical ground in Kant's transcendental idealism. But two differences between Kant's moral theory and two-kingdom dualism preserve the latter position's distinctive character. First, while Kant's theory is explicitly moralist, providing frameworks for deriving universal maxims of right and wrong behaviour, two-kingdom dualism is not: it

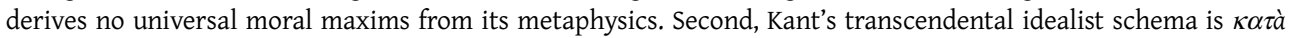
$\ddot{\alpha} v \theta \rho \omega \pi 0 v$ or 'according to the human' (Kant (1999), 643-644) in that it depends on human reason; as a result, implications drawn from it are characteristic of discourse in $\mathrm{K}_{\mathrm{W}}$ more generally in that they arise from and substantially depend on human resources. Two-kingdom dualism, on the other hand, appeals to metaphysical reference points in $\mathrm{K}_{\mathrm{G}}$, which are not constituted or dependent in this way.

34. 'The Schleitheim Confession of Faith, 1527' (Sattler (1945)).

35. Rom. 13:1 (ESV).

36. Showalter (2000).

37. Ibid.

38. 1 Tim. 2:3 (ESV).

39. Showalter (2000).

40. This symbiotic dynamic between two-kingdom dualists and state and military actors was apparent during clashes in Mosul between ISIS and US-led forces in early 2017. At this time, a Kurdish military base eight miles from Mosul furnished a team of Mennonite volunteers with military protection and accommodation adjacent to the base in order to encourage the volunteers to rebuild local houses. The volunteers gratefully accepted the military's protection even though they themselves would have been unwilling to use military force. A similar dynamic was evident in 2016 when the European Union and Turkey agreed to aggressive measures to stem the flow of refugees crossing the Mediterranean Sea to the Greek island of Lesvos. In response to this agreement, the United Nations, International Refugee Counsel, AIM, Red Cross, Doctors Without Borders, and Samaritan's Purse abandoned their aid operations in protest and to avoid implication in a decision they deemed immoral. However, Euro Relief, a Greek Christian organization overseeing a number of Mennonite volunteers, remained in the camp and assumed these organizations' aid responsibilities in partnership with the local government and police. While some aid workers felt morally hesitant about this decision, the decision was not ultimately based on the moral considerations that drove other humanitarian actors. Instead, sharply distinguishing themselves as citizens of $\mathrm{K}_{\mathrm{G}}$ from the decision made by leaders in $\mathrm{K}_{\mathrm{W}}$, Euro Relief continued to act as they deemed consistent with the metaphysics of $\mathrm{K}_{\mathrm{G}}$, risking their moral stature before other humanitarian agencies in order to continue to assist the refugees sailing ashore.

41. Two-kingdom dualists 'do not think it is our role to tell this kingdom how to run its affairs' (Showalter (2000)).

42. See Nietzsche (1996), 77-125. Two-kingdom dualism arguably evades Nietzsche's wide-ranging critiques of Christianity and Christian morality; indeed, it is even construable as a 'Nietzschean' position to the extent that it affirms Nietzsche's critiques while insisting that Nietzsche misconstrues Christianity when he casts it as a species of moralism.

43. Whereas morality obligates, or at least tries to, reality just is; instead of obligating, it invites a response. While this response might have behavioural implications, these implications can be rejected along with reality itself.

In this light, the fact that the purported reality of $\mathrm{K}_{\mathrm{G}}$ is not conclusively demonstrated is a feature of twokingdom dualism. While it might seem that problems would arise whether Christian metaphysical claims are in fact true or false - since their falsity would render two-kingdom dualism baseless while their truth might entail that people cannot legitimately choose to profess allegiance to $\mathrm{K}_{\mathrm{G}}$ - Christianity instead strikes an 
important balance between warrant and inconclusiveness when it presents itself both as a plausible historical narrative and as a humanly unbelievable paradox. While arguments and evidence might in principle lend even maximal warrant to Christian faith, Christian teaching also insists that Christian faith is fundamentally a gift that an individual could not achieve unilaterally (Ephesians 2:8-9). The point is Kierkegaardian: the 'objective uncertainty' of $\mathrm{K}_{\mathrm{G}}$ is an asset to which Christians 'hold fast' (Kierkegaard (1992), 207). This 'objective uncertainty' is crucial because it preserves the freedom of the individual to choose the kingdom to which she will profess allegiance: while her choice to pledge allegiance to $\mathrm{K}_{\mathrm{G}}$ is reasonable, her freedom not to do so is preserved. Moreover, it does not follow from the fact that Christianity's metaphysical claims are not conclusively demonstrated that there cannot be a fact of the matter as to their truth - or that they cannot provide a distinctively robust ballast for non-violence even for the person who is falsely convinced that they are true.

44. Harris (2005), 143.

\section{References}

Augustine (1998) The City of God Against the Pagans. Dyson RW (tr.). Cambridge, UK: Cambridge University Press. Arnold J (2018) State Violence and Moral Horror. New York, NY: State University of New York Press.

Chignell A (2007) Belief in Kant. The Philosophical Review 116, 323-360.

Curtis-Wendlandt L (2012) No right to resist? Elise Reimarus's 'Freedom' as a Kantian response to the problem of violent revolt. Hypatia 27, 755-773.

Estep W (1995) The Anabaptist Story. Grand Rapids, MI: Eerdmans.

Harris S (2005) The End of Faith: Religion, Terror, and the Future of Reason. New York, NY: W. W. Norton.

Haslanger S (2012) Resisting Reality: Social Construction and Social Critique. New York, NY: Oxford University Press. Hill T (1997) A Kantian perspective on nonviolence. The Journal of Ethics 1, 105-140.

Holmes RL (1973) The concept of violence in moral and political affairs. Social Theory and Practice 2, 387-408.

Hunter JD (2010) To Change the World. Oxford, UK: Oxford University Press.

Kant I (1999) Critique of Pure Reason. Guyer P and Wood AW (trs). Cambridge, UK: Cambridge University Press.

Kierkegaard S (1983) The Sickness unto Death. Hong HV and Hong EH (trs). Princeton, NJ: Princeton University Press.

Kierkegaard S (1985) Philosophical Fragments. Hong HV and Hong EH (trs). Princeton, NJ: Princeton University Press.

Kierkegaard S (1992) Concluding Unscientific Postscript to the Philosophical Fragments. Hong HV and Hong EH (trs). Princeton, NJ: Princeton University Press.

Kierkegaard S (1997) Without Authority. Hong HV and Hong EH (trs). Princeton, NJ: Princeton University Press. Mackie JL (1977) Ethics: Inventing Right and Wrong. New York, NY: Penguin.

McTaggart JME (1927) The Nature of Existence. Cambridge, UK: Cambridge University Press.

Nietzsche F (1996) On the Genealogy of Morals. New York, NY: Oxford University Press.

Sattler, M (1945) The Schleitheim Confession of Faith, 1527. Wenger JC (tr.). The Mennonite Quarterly Review 19, 247-253.

Showalter J (2000) Peace, justice, and simplicity. Lecture. Ministers Fellowship. Grantsville, MD.

Tolstoy L (2009) The Kingdom of God Is Within You. Garnett C (tr.). Portland, OR: The Floating Press.

Turner J (2005) Performing conscience: Thoreau, political action, and the plea for John Brown. Political Theory 33, $448-471$.

Van Bragt T (2010) Martyr's Mirror. Harrisonburg, VA: Herald Press.

Weaver A (2017) Humility, peacebuilding, and the limits of Christian pacifism. The Conrad Grebel Review 35, 240-248.

White S (2017) On the moral objection to coercion. Philosophy and Public Affairs 43, 199-231.

Whitworth A (2014) A problem deeper than politics. Mennonite Central Committee. Available at mcc.org/stories/ problem-deeper-politics.

Wolff RP (1969) On violence. Journal of Philosophy 66, 601-616.

Wolfsdorf DC (2019) On Goodness. New York, NY: Oxford University Press.

Yoder JH (1972) The Politics of Jesus. Grand Rapids, MI: Eerdmans.

Cite this article: Zimmerman C (2021). Anabaptist two kingdom dualism: metaphysical grounding for non-violence. Religious Studies 1-12. https://doi.org/10.1017/S0034412521000147 